\title{
1 Assessing the degradation of saline wetlands in an arid agricultural region in Spain
}

3 Soils and Irrigation Department, C.I.T.A., Government of Aragón. P.O. Box 727, 50080 Zaragoza, Spain.

\section{Abstract}

6 subjected to increasing agricultural pressure. Until now, no systematic study of their

8 degradation status has been performed, and no comprehensive map of these wetlands

9 has been available. Both subjects are addressed for the first time in this study. In

10 addition, we set up a conceptual tool for assessing saline wetlands degradation that 11 improves upon available methods within geomorphological, sedimentological or 12 hydrological frameworks. A wetlands inventory was produced and updated using 13 satellite data, field observations, and orthophotographs, together with the available 14 disperse data about these wetlands' toponymy and location. The degraded landscape 15 appearance of the surviving wetlands, mainly affected by agricultural intensification 16 —dumping and farming - has been qualitatively assessed.

17 Systematic descriptors of these saline wetlands - escarpment, stone dumping, 18 vegetation, and water- were selected and analyzed to identify the status and the

19 increase in degradation of these wetlands between 1988 and 2003 . At present, $50 \%$ of 20 the wetlands registered in 1988 have disappeared. Of the remaining wetlands, $30 \%$ have 21 been invaded by crops and stone debris has increased in $63 \%$. The smoothing of the 22 escarpment appears to be a key degradation symptom. In the absence of field

\footnotetext{
${ }^{1}$ Corresponding author. Tel.: + 34976716 395; fax: + 34976716 335. E-mail address: ccastanneda@aragon.es
} 
monitoring programs, the integration of remote sensing and GIS with field data was a

24 powerful tool to track recent changes and assess wetland disturbance. A baseline for comparative analyses and further agro-environmental monitoring has been established.

27 Keywords: aridity; landscape degradation; Monegros; playa-lakes; salinity

\section{Introduction}

Wetlands are among the most valuable and productive ecosystems on earth,

31 necessitating research to ensure wise development and protection (Ramsar Convention

32 Secretariat 2004). Worldwide, many wetlands were lost and degraded during the 20th

33 century by human pressures (Dahl and Johnson, 1991; Davis and Froend, 1999; Tiner,

34 2002), especially by agricultural intensification (OECD, 1996) and loss might increase in

35 the future (Millennium Ecosystem Assessment, 2005). In Europe, a regional overview of

36 wetlands degradation recognized the high pressure of urban and industrial development

37 (Stevenson and Frazier, 1999). Since the Ramsar Convention in 1971, various initiatives

38 have been undertaken in order to increase conservation awareness about these habitats.

39 The Medwet long-term collaborative program hopes to ensure the wise use of wetlands

40 throughout the Mediterranean, emphasizing not only ornithology but many wetland

41 values and functions (Costa et al., 1996). In order to protect these vulnerable

42 environments it is necessary to monitor the changes produced, their causes and

43 consequences (Tomàs-Vives, 1996). Wetland inventories are incorporating remote

44 sensing and GIS techniques to conservation planning efforts in order to characterize land 45 uses and habitats (Tiner, 2004). 
47 Finlayson and Rea (1999). Arid-zone wetlands especially, for which there is little or no 48 information, are poorly mapped (Finlayson et al., 1999). Saline wetlands in arid climates are scarce in Europe and are not well represented in inventories and 50 conservation plans. In the Monegros Desert of northeastern Spain the saline wetlands, 51 locally named "saladas", are playa-lakes (Castañeda et al., 2005a) and other closed saline depressions of high scientific and environmental value. Similar wetlands from other semiarid regions throughout the world have been inventoried and classified. For example, the U.S. Fish and Wildlife Service classifies these wetlands as isolated playas and salt flats (Tiner et al., 2002). The U.S. Environmental Protection Agency (2005) has included Playa-lake in its system of classification of wetlands in order to update the Cowardin et al. (1979) system used in the National Wetlands Inventory (Cowardin and Golet, 1995). The U.S. Geological Survey supports wetland hydrological research that promotes their restoration (Hunt et al., 1999). Endorheic systems similar to those of Monegros have been added to the South African National Wetland Inventory (Dini et al., 1998) in recognition of the significant ecological role played by pan ecosystems in southern Africa.

Southern High Plains playas incorporated into farming systems have been studied by Haukos and Smith (1994) for biodiversity purposes. Standard procedures for studying wetlands in the field are difficult to apply in playas and may require specific protocols for delineation purposes (Lichvar et al., 2004; 2006) as well as inferential study and professional judgment (Brosttoff et al., 2001).

The saladas of Monegros are scattered throughout a landscape undergoing 69 significant transformations due to agricultural intensification that includes irrigation of new croplands. Land consolidation and new infrastructures affect the entire area (Figure 
71 1) and some saladas have already been destroyed or are greatly affected. On the other

72 hand, the Birds Directive and the Habitats Directive - the two main pieces of

73 legislation of EU nature conservation policy - deal with the conservation of European

74 wildlife, focusing on the protection of sites as well as species. These sites make up the

75 Natura 2000 network, the cornerstone of EU nature protection policy. Half of the

76 overall area of the Monegros saladas has been proposed for inclusion in the

77 Mediterranean region of the expanded Natura 2000 network. However, at present there are no standardized procedures to describe the degradation status of saladas or monitor the effects of land-use management.

The aim of this research is to establish a methodology for the systematic study of saline wetlands in southern Monegros. This objective includes two main purposes: (i) to accomplish an updated and unified inventory and (ii) to depict the changes in these wetlands in the last decades by comparing current observations with historical data. We have taken advantage of remotely sensed data and a geographical information system (GIS) as a supporting tool to integrate the information recovered from different sources and scales. This study takes an eco-centric approach (Eckersley, 1992), based on habitat naturalness and preservation.

\section{Study area}

Saline wetlands in the Monegros desert (Figure 1), one of the most arid regions in

91 Europe (Herrero and Snyder, 1997), are scattered throughout an agricultural landscape

92 of about $400 \mathrm{~km}^{2}$. The almost one hundred closed depressions, some of them hosting 93 playa-lakes, are isolated and slightly hidden in smooth and flat karstic depressions

94 (Figure 2) and flat-bottomed valleys. They usually stand out in the landscape due to one or more of the following characteristics: a flat bed topography with water and/or salt 
96 efflorescence, permanently wet soil related to their groundwater discharge function

97 (Castañeda and Herrero, 2005), and halophytes.

Figure 1

The saladas play an important role in the regional hydrology, having a close

101 connection with hypersaline aquifers (Samper and García-Vera, 1998; Castañeda and

102 García-Vera, in revision) and are recognized in the EU Natura2000 network

103 (Domínguez et al., 2006) for hosting endemism and protected species (Pedrocchi, 104 1998). They also provide habitats for algae and extremophile microbes.

Most of the largest saladas are bordered by a sharp escarpment from one to twenty meters in height which primarily delimits the northern and southern extent of the depressions. The common orientation of these escarpments is NW-SE. The higher the escarpment and the longer its lateral continuity the better preserved the salada, since height and continuity increase confinement and hamper agricultural invasion. Many

110 escarpments have been smoothed to facilitate plowing towards the bottoms, increasing 111 sedimentation, as observed in similar playa environments in the U.S. by Haukos and 112 Smith (1994).

116 and wet bottoms with halophytes which indicate their discharge hydrological function.

117 The durum (Triticum durum Desf.) or barley (Hordeum vulgare L.) fields surrounding the

118 saladas have numerous stones and boulders. Since the plowing must be deep enough to

119 retain the scarce rains, stones are continuously removed. Stone dumping in the saladas cover the escarpment and borders of most saladas, advancing towards the mud flat or 
121 vegetated bottom. The halophytes are suffocated and geomorphologic processes are

122 modified. Intermittent water occurrence in the saladas, an outstanding feature in this arid 123 zone, is critical to the conservation of these habitats. Water and escarpment hinder

124 agricultural use; as soon as the surface water evaporates, the smaller saladas are plowed, 125 to obtain agricultural subsides.

\section{Material and methods}

128 The saladas boundaries were delineated from an April 2, 1997, Landsat image.

129 We selected the wettest year during the last two decades, with an annual average

130 rainfall of $535 \mathrm{~mm}$ for the Petris Weather Station (Figure 1) against an average of 350

$131 \mathrm{~mm}$ for the period covered by that station, 1974-2006 (Figure 3). For this purpose we

132 performed a visual interpretation of the most suitable Landsat bands (Castañeda et al.,

133 2005b), with the assistance of topographic maps at scales of 1:25000 and 1:50000.

Figure 3

136 Disperse data about the saladas — some of them unpublished- were collected 137 and those containing geographical coordinates (Pueyo-Mur, 1978; Pedrocchi, 1988;

138 1998; Comín and Sanz, 1989; Berga, 1993) were represented in a geographic

139 information system together with our remotely sensed mute map. Location and 140 toponymy from each author were revised, standardized, and compared with our map 141 and with two non-georeferenced sketches from Balsa et al. (1991) —including one 142 hundred saladas, all numbered and many with names-, and from Sancho and 143 Gutiérrez (1993) — showing geomorphologic features such as karstic depressions and 
144 sinkholes-. A subsequent field campaign inspection was carried out aided by black

145 and white orthophotographs from 1997 at 1:10000 scale.

146 A new geospatial saladas database was created containing only those saladas

147 clearly identified in the field. In the lack of soil and vegetation maps, we systematically

148 recorded in the field four features for each salada - the systematic descriptor of the

149 saladas (SDS) - Escarpment continuity, stone dumping, natural vegetation and crops,

150 were considered visual indicators of status, together with the surface area of each

151 salada, extracted from the GIS. In the lack of detailed topographic maps, escarpment

152 continuity/smoothing was evaluated in the field.

153 When estimating the importance of water presence, we take into consideration the

154 rainfall registered in the area. At the time the field work was conducted, water presence

155 was not a degradation symptom. However, water presence has been recorded in the

156 field because of its significance for hydrologic behavior comparisons in the advancing

157 irrigation works scenario and also because it is often taken into account by decision

158 makers as the only feature to indicate the saladas existence. For this purpose we studied

159 the water presence from 1984 to 2004 using satellite images (Castañeda and Herrero, 160 2006).

161 Several categories of SDS were established to rank each descriptor, from 162 absence to maximum observed degree (Table 1). In addition, we collected photographs 163 that revealed the changing appearance of the saladas through the seasons during a field 164 campaign spanning from October 2002 through June 2003, and we also grouped the 165 saladas in different classes according to their general landscape appearance.

166 In order to detect possible changes in conservation status, the next step was to 167 compare, for each salada, our SDS with the analogous observations recorded 15 years 168 before by Comín and Sanz (1989). We matched the SDS categories from the two 
surveys, adopting an integrated classification — last column of Table 1 -, disregarding

170 the most detailed classification, when necessary. In order to discard the possible effects

171 of the surface area estimations techniques, only differences $>15 \%$ in the size of the

172 saladas were considered. Loss of confining properties of the escarpment, dumping, crop

173 invasion, and decrease in size are considered as degrading changes in the saladas. The

174 number of changed SDS is used to qualify the degradation for each salada.

Table 1

\section{4. Results and discussion}

\subsection{Updated Inventory 2003}

Agricultural intensification and irrigation works make it difficult to recognize some saladas, both in the field and in the recent earth surface images. The largest and wettest saladas, as well as those preserving their escarpment and native vegetation, were detected and delineated in the Landsat image of April 2, 1997. A first inventory was obtained containing 39 saladas ranging from 1.8 ha to 200 ha. The visual analysis of the

184 orthophotographs and the field data recorded during 17 visits allowed a detailed 185 drawing of the saladas borders and enlarged the remotely sensed inventory. The resulting map, labeled Inventory 2003, shows a total wetland area of 860 ha, distributed in 53 saladas (Figure 1).

Several saladas described in previous studies were not recognized in the Landsat image, mostly because of farming, as confirmed in the field. Many small saladas

190 without geographic references recorded by Balsa et al. (1991) and not detected by us in

191 the satellite image, were located in the orthophotographs. Vestiges of saladas were also

192 detected on the ortophotographs from arrangements of terrain features or from 
193 differences in vegetation and soil color, evidencing the destruction of many of the

194 depressions mapped by Balsa et al. (1991) or by Sancho and Gutiérrez (1993). These

195 two sketches were not integrated into the GIS due to the lack of georeferenced points.

196 The saladas listed by Pedrocchi (1988), Comín and Sanz (1989), and Balsa et al. (1991)

197 contained 95, 85, and 100 saladas, respectively; in which $48 \%, 33 \%$ and $76 \%$ of the

198 saladas were given names. Pueyo-Mur (1978), Berga (1993) and Pedrocchi (1998)

199 monitored a limited number of saladas, less than 25 , primarily including those with

200 more water presence.

201 The coordinates given to each salada differ between authors. Although they all used 1:50,000 topographic maps, they followed different criteria to assign coordinates: the NW vertex, along the North limit, or at its inner point. Therefore, several saladas

204 came to be represented by the same point; in other cases the same salada was located at 205 different points. Other differences came from the poor legibility and physical 206 degradation of some revised documents. Location ambiguities and toponymy 207 disagreement were clarified by consulting non-georeferenced sketches from Balsa et al. 208 (1991) — drawing a hundred saladas, all numbered and many with names - and from 209 Sancho and Gutiérrez (1993) - depicting geomorphologic features such as karstic 210 depressions and sinkholes-. The most complete toponymy, from Balsa et al. (1991), 211 was maintained for our Inventory 2003, in which "clota" was the term used for the 212 nameless saladas. This updated inventory contained those 53 saladas clearly identified 213 in the field and the toponymy used by the different authors.

214 Only 31 of the inventoried saladas - those with more water presence and those 215 with marked boundary - are shown on the official topographic maps; they were 216 qualified as marshes in the legend, 14 of them without a toponym. The absence of some 
217 saladas in these maps is not related to size but to cultivation. This can be attributed to

218 the method of production of these maps based on photointerpretation.

\subsection{Assessment of the condition class of the saladas}

The maps shown in Figure 4 represent the distribution of the SDS recorded in 2003. As visual indicators, they provided sound information about the status of the 53 saladas. More than $75 \%$ of them present an easy access due to their smoothed escarpment; of these, $28 \%$ are not recognizable as saladas at the time of inventory because they are incorporated into the plowed area or are affected by roads and subsurface pipe drains installed by the irrigation works in progress. Some $90 \%$ of the studied saladas show stone dumping; $80 \%$ are invaded by crops to some degree. The saladas least invaded by crops are the ones that contain water most often.

Figure 4

230

Flooding and soil salinity in the borders were traditionally the limitations for cultivation around the saladas. However, at present, the SDS recorded in this study reveal a breaking-down of these limits, perhaps attributable to the availability of machinery and to subsidies from the European Union - Common Agricultural Policythat reward low input extensive crops.

It is not clear from the data presented how the SDS recorded reveal a machinery or crop subsidies would affect flooding/soil salinity. 
To carry out comparative analyses and describe this environment, the saladas were classified in the field according to their landscape appearance by means of external expert judgment. Six categories or condition classes describing the degree of

244 conservation were established, from unrecognizable to pristine - third column in Table 2-. These condition classes are a useful reference for understanding and monitoring 246 these habitats.

The inventoried saladas average 16 ha in surface area, with $77 \%$ less than 20 ha; those larger than 20 ha are of playa-lake type. Condition class was strongly correlated with salada size (Figure 5). The unrecognizable saladas averaged 6 ha, and the average size for each category increased steadily, reaching 43 ha for those with pristine landscape appearance. For all the saladas, $26 \%$ were classified in the pristine or slightly disturbed landscape appearance groups. These well-preserved saladas range from 234 ha to 8 ha in size, contained water in 1988 and 2003, and had the highest historical water occurrence (Castañeda and Herrero, 2005). This is the case of Salineta, with 23 ha and the maximum water and salt occurrence (Figure 2b). Decades ago, this salada was a profitable site for artisan salt production, an activity with limited habitat disturbance that caused local people to appreciate the value of saladas.

Figure 5

4.3. Saladas degradation: observed changes between 1988 and 2003

While in 1988 Comín and Sanz (1989) described 85 saladas, only 40 of them were recognized by us in 2003 and many saladas have become unrecognizable in the field. However, examination of the saladas' shape and size in the Landsat image and the

264 orthophotograph shows past borders faded by tillage. In contrast, 13 saladas described in 2003 did not appear in that inventory. Table 2 shows the changes observed in the 40 
saladas recorded in both inventories, together with their condition class as established in the Inventory 2003.

Taking into account the established $15 \%$ threshold for changes in the saladas size, $38 \%$ of the saladas have decreased in extent. All belong to the saline closed depressions type, locally named "clotas" and "hoyas", which do not exhibit surface water yearly but do have a cover of halophytes. Fully $23 \%$ of the saladas show escarpment degradation, i. e., a confining escarpment has changed into a smooth or non-confining escarpment, 273 probably due to flattening to allow farming or for machinery to pass. Of all these 274 degraded saladas, Agustín, Farnaca, and Benamud, ranging from 70 ha to 12 ha in size, are the most relevant in terms of the halophytic and endemic plants they host (Domínguez et al., 2006). Thus, $43 \%$ of the saladas retained their confining escarpment, and 34\% retained their smooth escarpment.

Saladas with no detectable changes between 1988 and 2003 in terms of cropping have been grouped in three categories: not cultivated, partially cultivated and totally cultivated, involving $10 \%, 50 \%$, and $10 \%$, of the whole sample set, respectively. This leaves $30 \%$ of the saladas that were affected by new cropping. These are also grouped in three categories: (1) not cultivated in 1988 and partially cultivated in 2003; (2) partially cultivated in 1988 and totally in 2003; (3) not cultivated in 1988 and totally

284 cultivated in 2003 . These saladas rank from 12 ha to 70 ha, in size. Some of them, such as Camarón and Pueyo, are playa-lakes and host water yearly; others, like Agustín, host significant halophytic plants, both in extent and diversity. Almost all of them have a smooth escarpment and four were unrecognizable in 2003, totally incorporated to 288 farming.

Waste dumping has increased in recent years, as has the presence of industrial machinery and construction traffic. From 1988, dumping has affected $63 \%$ of the 
saladas regardless of their size and water presence; less than the $8 \%$ remain free of

292 dumping, due to cultivation. All told, $92 \%$ of the saladas exhibit dumping in the center and/or borders, covering the halophilous vegetation to some degree.

The last column of the Table 2 summarizes the number of SDS features changing between 1988 and 2003, with only five saladas qualified with 0, i.e., without any change in their initial appearance. All the other saladas have some form of effective degradation in one to three of their features. As observed, these changes (degradation) are not exclusively related to their size, though the smaller saladas certainly look in the field to be the ones most damaged. Almost all the saladas holding water in both years also demonstrate less features changed. All the saladas with 3 changing SDS did not hold water in both years; almost those saladas holding water in both years have only 1 feature changed The standing water observed during the humid period of the field campaign (January to May) hampers the plowing of the saladas; however, some of them have been tilled in June, when water evaporates.

Endemism and priority Natura2000 habitats, all of which are represented in the study area, have not been used here to categorize the saladas interest since biodiversity is a common feature. Other factors such as the saladas location with respect to the current installation of new irrigated schemes, or with respect to protected areas, ought to be taken into account in further analyses and be incorporated into the irrigation system

310 design.

\section{Conclusions.}

The saladas, usually considered agricultural wasteland or barren terrain from the

315 point of view of productivity, have undergone a siege of agricultural intensification 
316 constrained only by spots of flooding and extreme salinity. The traditional dry farming

317 around these saline wetlands is also changing over to irrigation, increasing their

318 degradation. For monitoring and conservation purposes, we have looked at the

319 inventory and described the status of these arid-zone wetlands, for which there is little

320 or no information. The updated Inventory 2003 has been developed to better understand

321 the saladas system of Monegros. The field inspections allowed grouping the saladas in

322 several condition classes according to their landscape appearance. This grouping

323 illustrated the degree of conservation of the saladas and built a baseline for comparative

324 analyses and further monitoring.

325 The systematic descriptors of the saladas (SDS) were established to assess in 326 more detail their status as of 2003. These descriptors showed the high percentage of 327 saladas that had been disturbed to some degree - affecting their escarpment and native 328 vegetation - and those unrecognizable as functional wetlands because the soil surface 329 features related with groundwater discharge had been eliminated. Comparing our SDS 330 with similar observations from other authors 15 year ago, we obtained factual 331 information on the saladas' degradation, i. e. the observed changes between 1988 and 332 2003. This degradation, though more visible in the smallest saladas, affects all of them regardless of their size or the presence of water. Escarpment smoothing, crop invasion, 334 stone and debris dumping, and decrease in size have affected $23 \%, 30 \%, 63 \%$, and $38 \%$ 335 of saladas, respectively.

336 This study attempted to perform a systematic overview of the saladas to quantify

337 features otherwise difficult to measure in the field, and to contrast the results spatially 338 and temporally. This work increases knowledge about these wetlands and can be a 339 baseline for agro-environmental monitoring purposes. 


\section{Acknowledgements}

The Spanish Ministry of Education and Science and FEDER supported this work with the research project AGL2006-01283, and with the grant EX2006-0347 to the first author. We acknowledge the careful revision and suggestions of the unknown editor of this article and the referees: S.P. Faulkner and C.M. Finlayson.

\section{References}

Balsa, J., Guerrero, C., Pascual, M.L., Montes, C., 1991. Las saladas de BujaralozSástago y las saladas de Chiprana: riqueza natural de Aragón. Empelte 7, Caspe, Zaragoza, Spain.

Berga, A., 1993. Relaciones clima-agua-suelo-subsuelo en Monegros II. PhD Thesis. University of Lleida, Spain.

Brosttoff ,W., Lichvar, R., Sprecher, S., 2001. Delineating playas in the arid southwest. A literature review. US Army Corps of Engineers. Technical Report ERDC TR$01-4$

Castañeda, C., García-Vera, M.A., 2007. Water balance in the playa-lakes of an arid environment, Monegros, NE Spain, Hydrogeology Journal, in revision.

Castañeda, C., Herrero, J., 2005. The water regime of the Monegros playa-lakes established from ground and satellite data. J. Hydrol. 310, 95-110.

Castañeda, C., Herrero, J., 2006. Using Landsat imagery for reconstructing wetlands inventory and functional status in Monegros, NE Spain. Proceedings GlobWetland Symposium, Frascati, Italy, October 2006. 
363 Castañeda, C., Herrero J., Casterad, M.A., 2005a. Facies identification within the playalakes of the Monegros Desert, Spain, with field and satellite data. CATENA 63, $39-63$.

366 Castañeda, C., Herrero, J., Casterad, M.A., 2005b. Landsat monitoring of playa-lakes in the Spanish Monegros Desert. J. Arid. Environ. 63, 497-516.

Comín, F.A., Sanz, M.A., 1989. Limnología de las lagunas del polígono Monegros II. In Madrid.

Costa, L.T., Farinha, J.C., Hecker, N., Tomàs-Vives, P., 1996. Mediterranean Wetland Inventory: a Reference Manual. MedWet/Instituto da Conservaçao da Naturaleza/Wetlands International Publication. Vol. 1.

Cowardin, L.M., Carter, V., Golet, F.C., LaRoe, E.T., 1979. Classification of wetlands and deepwater habitats of the United States: U.S. Fish and Wildlife Service, FWS/OBS 79/31.

Cowardin, L.M., Golet, F.C., 1995. US Fish and Wildlife Service 1979 wetland classification: A review. Vegetatio 118, 139-152.

Dahl, T.E., Johnson, C.E., 1991. Status and Trends of Wetlands in the Conterminous United States, Mid-1970's to Mid-1980's. U.S. Department of the Interior, Fish and Wildlife Service, Washington, D.C.

Davis, J.A., Froend, R., 1999. Loss and degradation of wetlands in southwestern Australia: underlying causes, consequences and solutions. Wetlands Ecology and Management 7, 13-23.

Domínguez, M., Conesa, J.M., Pedrol, J., Castañeda, C., 2006. Una base de datos georreferenciados de la vegetación asociada a las saladas de Monegros. XII 

2006. Granada, Spain.

Dini, J., Cowan G., Goodman P., 1998. South African National Wetland Inventory. Proposed wetland classification system for South Africa. [Cited 01 Feb 2007]. Available on: http://www.environment.gov.za/soer/nsoer/resource/wetland/index.htm

Eckersley, R., 1992. Environmentalism and Political Theory: towards an ecocentric approach. State University of New York Press.

Finlayson, C.M., Rea, N., 1999. Reasons for the loss and degradation of Australian wetlands. Wetlands Ecology and Management 7, 1-11.

Finlayson, C.M., Davidson, N.C., Stevenson, N. 1999. Report from Workshop 4: Wetland Inventory, Assessment and Monitoring - Practical Techniques and Identification of Major Issues. In Wetlands - A Source of Life. Conclusions of the

Herrero, J., 1982. Salinidad del suelo en salobrares de Monegros y Somontano oscense como condicionante de la vegetación. Institución Fernando El Católico, Zaragoza, Spain.

Herrero, J., Snyder, R.L., 1997. Aridity and irrigation in Aragón, Spain. J. Arid. Environ. 35, 55-547.

410 Hunt, R.J., Walker, J.F., Krabbenhoft, D.P., 1999. Characterizing Hydrology and the importance of ground-water discharge in natural and constructed wetlands. Wetlands 19(2), 458-472. 
413 Lichvar, R., Gustina, G., Bolus, R., 2004. Ponding duration, ponding frequency, and 414 field indicators: a case study on three Calfornia, USA, playas. Wetlands 24(2), 406-413.

416 Lichvar, R., Brostoff, W., Sprecher, S., 2006. Surficial features associated with ponded water on playas of the arid southwestern United States: indicators for delineating regulated areas under the Clean Water Act. Wetlands 26(2), 385-399.

Millennium Ecosystem Assessment, 2005. Ecosystems and human well-being: wetlands and water synthesis. A report of the Millennium Ecosystem Assessment. World Resources Institute, Washington, DC.

Pedrocchi, C., 1988. Bases limnológicas para la conservación y gestión de los humedales de Aragón. PCB-11/87. Government of Aragón. Zaragoza.

Pedrocchi, C. (ed.), 1998. Ecología de Los Monegros. Instituto de Estudios Altoaragoneses, Huesca.

Pueyo-Mur J.J., 1978. La precipitación evaporítica actual en las lagunas saladas del área Bujaraloz, Sástago, Caspe, Alcañiz y Calanda. Revista del Instituto de Investigaciones Geológicas 33, 5-56.

OECD 1996. Guidelines for aid agencies for improved conservation and sustainable use of tropical and subtropical wetlands. Organisation for Economic Co-operation and Development, Paris, France.

432 Ramsar Convention Secretariat, 2004. Ramsar handbooks for the wise use of wetlands. Ramsar Convention Secretariat, Gland, Switzerland.

434 Samper, F.J., García-Vera, M.A., 1998. Inverse modeling of ground-water flow in the 435 semiarid evaporitic closed basin of Los Monegros, Spain. Hydrogeol. J. 6, 33-49. 
436 Sancho, C., Gutiérrez, M., 1993. Geomorphological features of the Bujaraloz salt lakes. $2^{\text {nd }}$ Intensive Course on Appied Geomorphology: Arid Regions, 241-243. Zaragoza.

Stevenson, N.J., Frazier, S.1999. Status of national wetland inventories in Africa. In: Global Review of Wetland Resources and Priorites for Wetland Inventory. Finlayson, C.M. and A.G. Spiers, Hrsg. Supervising Scientist Report 144, Canberra, Australia.

Tiner, R.W. (compiler), 2002. Watershed-based Wetland Planning and Evaluation. A Collection of Papers from the Wetland Millennium Event (August 6-12, 2000; Quebec City, Canada). Association of State Wetland Managers, Inc., Berne, NY. $141 \mathrm{pp}$.

Tiner, R.W., 2004. Remotely-sensed indicators for monitoring the general condition of "natural habitat" in watersheds: an application for Delaware's Nanticoke River watershed. Ecological Indicators 4, 227-243.

Tiner, R.W., Bergquist, H.C., DeAlessio, G.P., Starr, M.J., 2002. Geographically Isolated Wetlands: A Preliminary Assessment of their Characteristics and Status in Selected Areas of the United States. U.S. Department of the Interior, Fish and Wildlife Service, Northeast Region, Hadley, MA.

454 Tomàs-Vives, P. (ed.), 1996. Monitoring Mediterranean Wetlands: a methodological 455 guide. MedWet publication; Wetlands International, Slimbridge, UK and ICN, Lisbon. Feb 2006. [Cited 01 Feb 2007]. Available on: http://www.epa.gov/owow/wetlands. 
Table 1. Systematic descriptors of the saladas (SDS) as recorded in the inventories of 1988 and 2003, and their aggregation —-sketched by dot lines - into simplified categories for comparison.

\begin{tabular}{|c|c|c|c|}
\hline \multirow{2}{*}{$\begin{array}{l}\text { Systematic } \\
\text { descriptor }\end{array}$} & \multicolumn{2}{|c|}{ Original records } & \multirow{2}{*}{ Categories of SDS } \\
\hline & 1988 & 2003 & \\
\hline \multirow{6}{*}{ Escarpment } & \multirow{2}{*}{ Significant* } & Very significant & \multirow{2}{*}{ Confining escarpment } \\
\hline & & Significant & \\
\hline & Smooth or not & Smooth & \multirow{4}{*}{ Smooth escarpment } \\
\hline & significant & \multirow{2}{*}{ Very smooth } & \\
\hline & \multirow{2}{*}{ Plain depression } & & \\
\hline & & Unrecognizable & \\
\hline \multirow{5}{*}{ Dumping } & Absent & Absent & Without stone dumping \\
\hline & \multirow{4}{*}{ Present } & In escarpment & \multirow{4}{*}{ With stone dumping } \\
\hline & & In center & \\
\hline & & Completely & \\
\hline & & covered & \\
\hline \multirow{4}{*}{ Cropping } & Not cultivated & Not cultivated & Not cultivated \\
\hline & Slopes cultivated & Partially cultivated & Partially cultivated \\
\hline & Bottom cultivated & \multirow{2}{*}{ Totally cultivated } & \multirow{2}{*}{ Totally cultivated } \\
\hline & Totally cultivated & & \\
\hline \multirow{3}{*}{$\begin{array}{c}\text { Surface } \\
\text { area }\end{array}$} & \multirow{3}{*}{ ha } & \multirow{3}{*}{ ha } & Decreased \\
\hline & & & Invariable \\
\hline & & & Increased \\
\hline \multirow{2}{*}{$\begin{array}{c}\text { Water } \\
\text { presence }\end{array}$} & Dry & Without water & Without water \\
\hline & Flooded & With water & With water \\
\hline
\end{tabular}

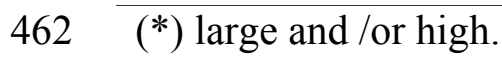


463 Table 2. The 40 compared saladas: name, extent, condition class, and features registered 464 in, along with water presence observations. Changes between 1988 and 2003 are 465 outlined in grey; $\left({ }^{+}\right)$: saladas detected in Landsat TM images.

466 


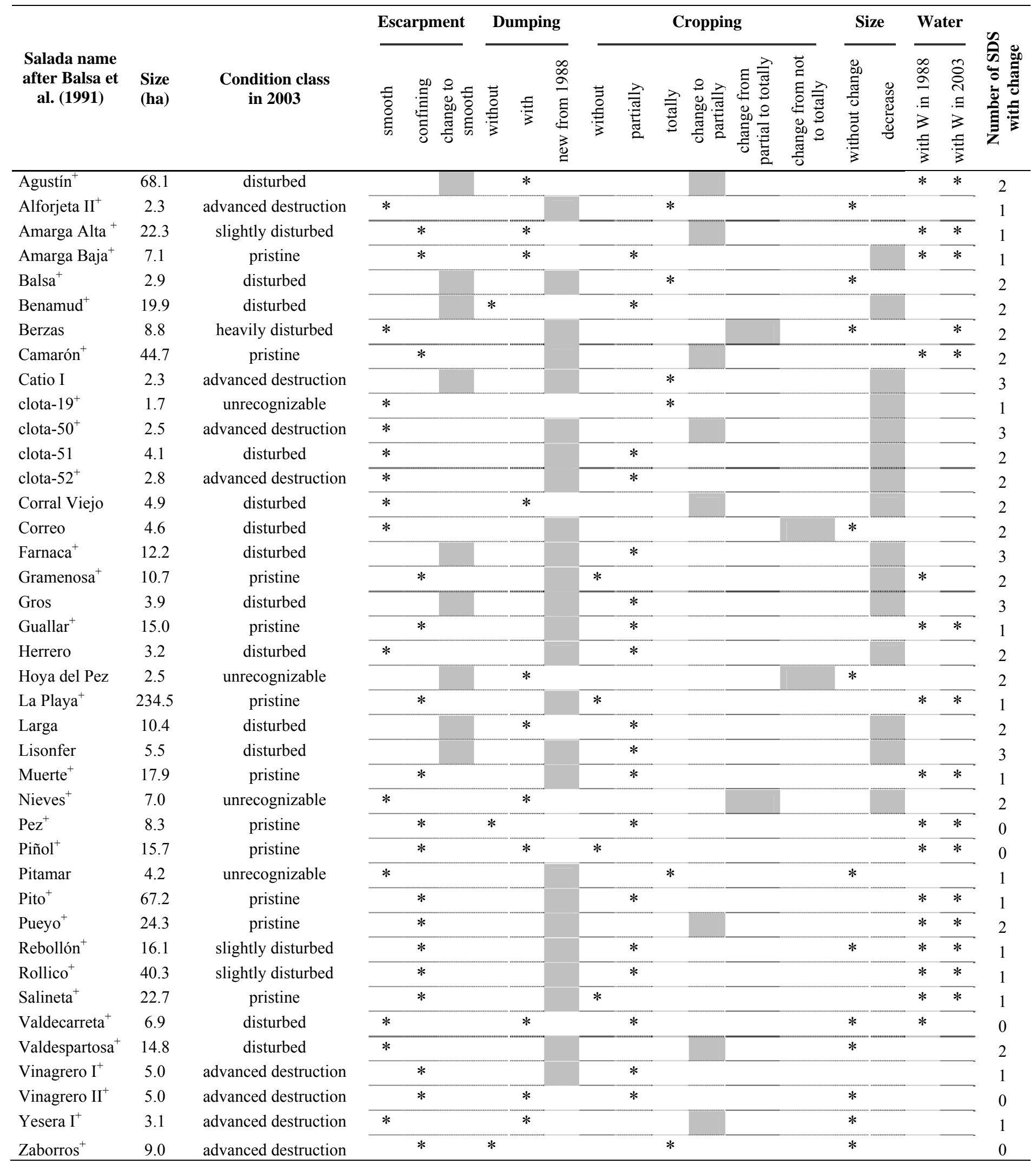


472 Figure 1. Location of the Monegros playa-lakes.

473 Figure 2. Different height of the escarpment bordering the saladas: (a) in Pez, the native 474 vegetation is better preserved when the escarpment is big; (b) the Salineta bottom and escarpment in a dry period.

476 Figure 3. Annual rainfall for the Petris Weather Station, located in the study area, from 1974 to the present and period covered by Landsat TM satellite.

478 Figure 4. The status of the Inventory 2003 illustrated by means of the Systematic Descriptors of the Saladas: escarpment, stone dumping, crop invasion, and water presence. Water presence was obtained from a series of satellite observations (Castañeda and Herrero, 2006).

482 Figure 5. Classes established to group the landscape appearance of the saladas in the Inventory 2003: number of saladas (n), surface extent and median (red plus), in ha, in each condition class. 


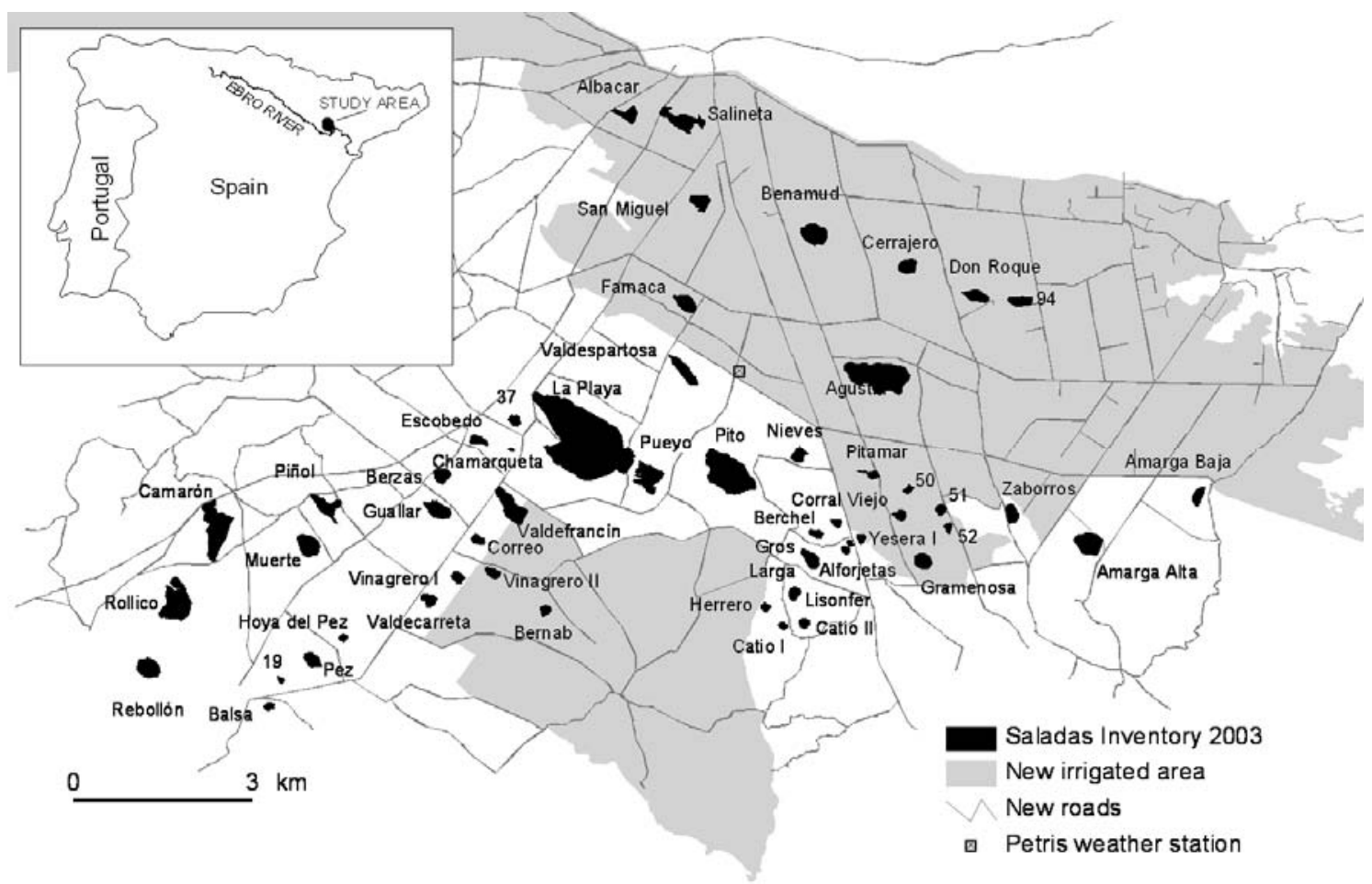

486

487 


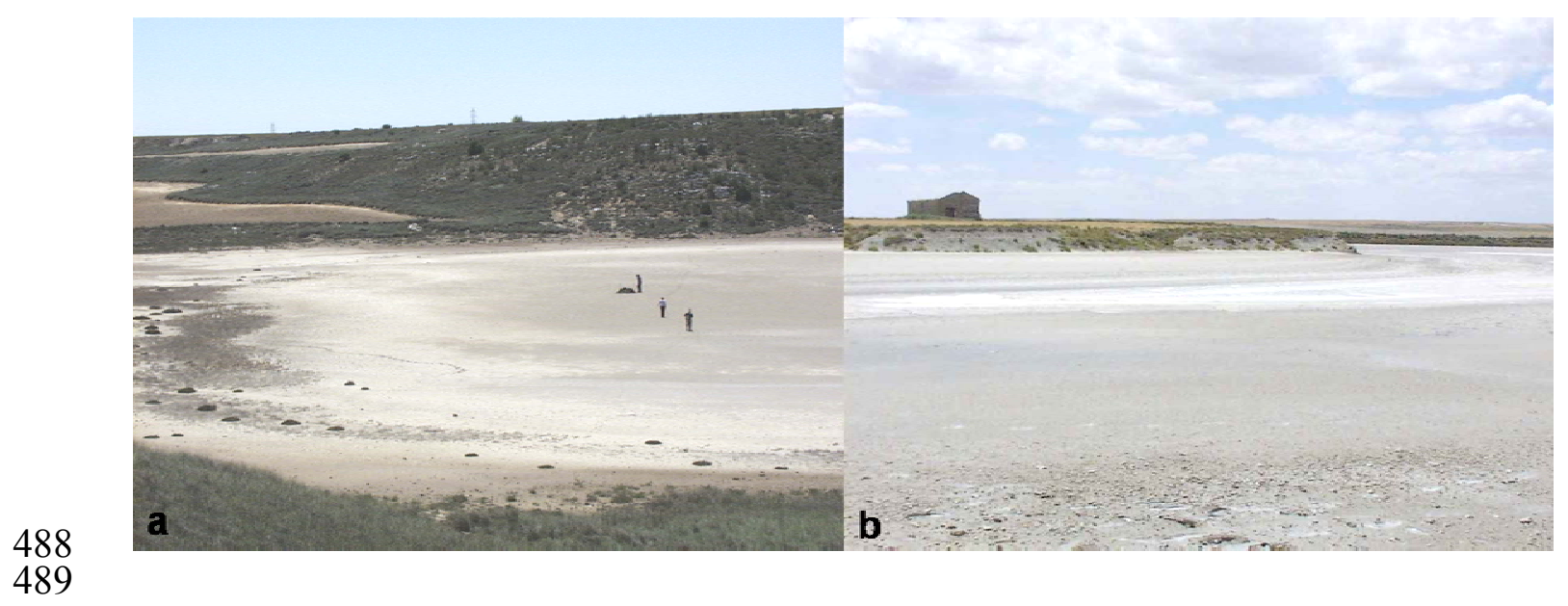




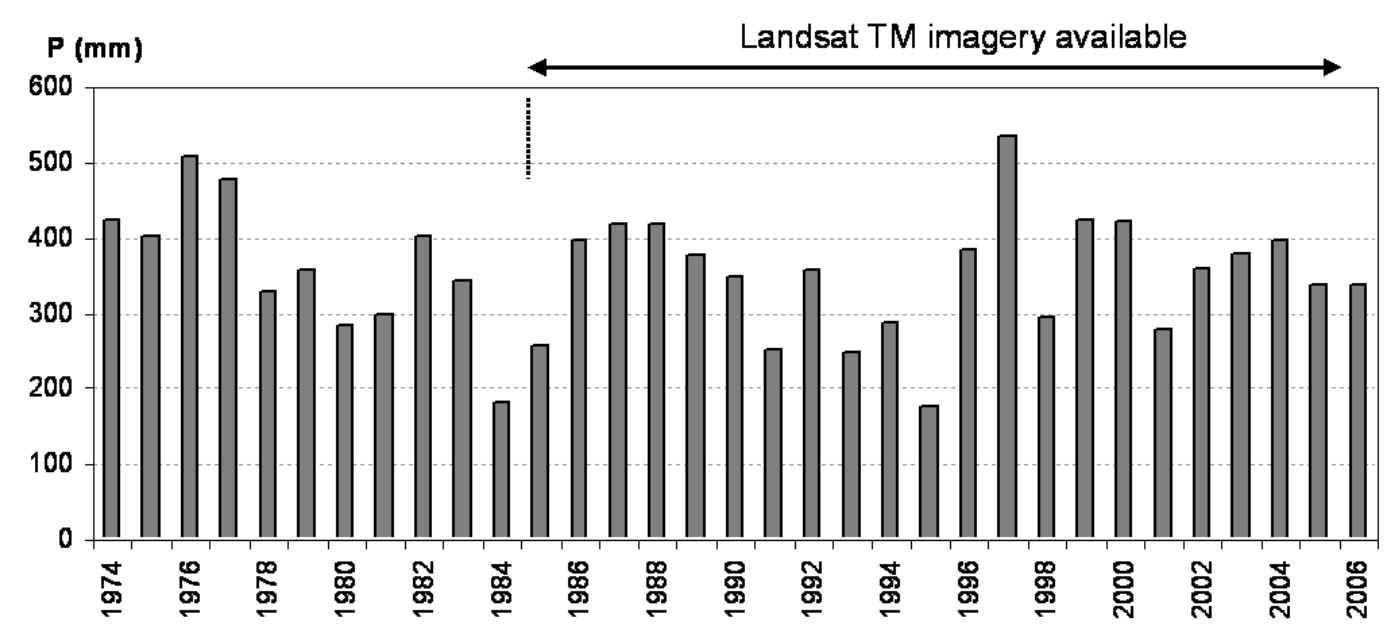




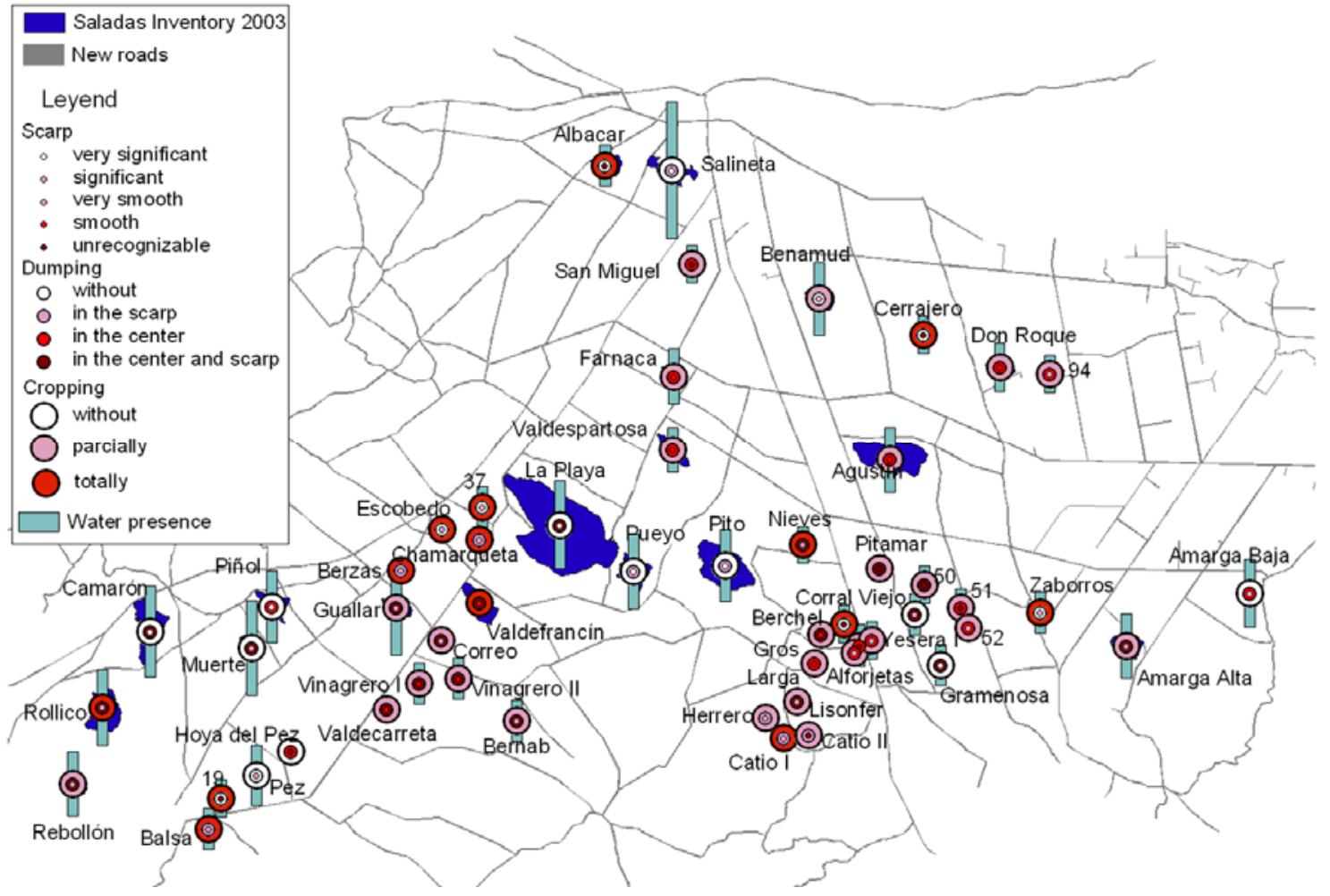




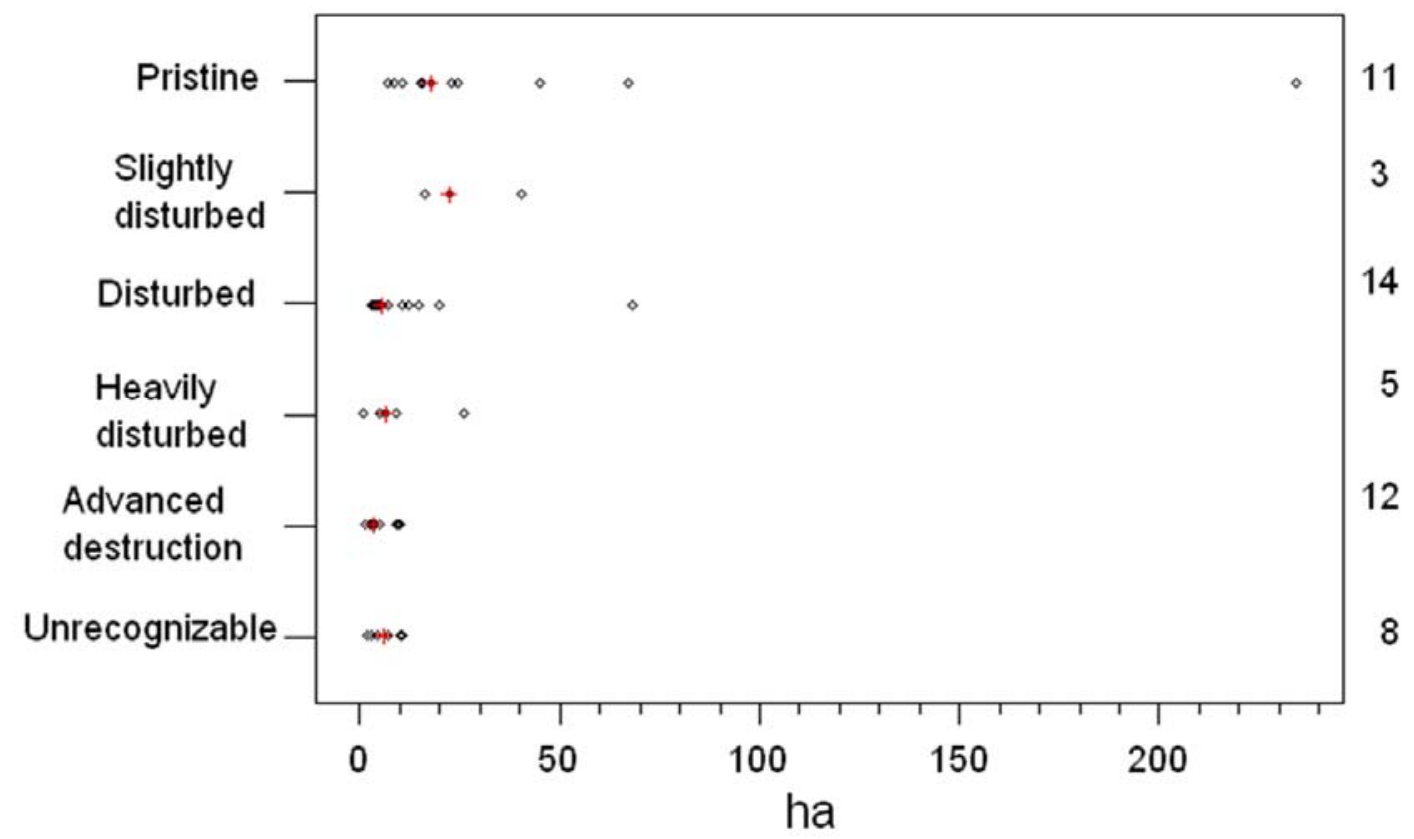

494

495 